\title{
A TEORIA DO DIREITO PENAL DO INIMIGO: UMA ANÁLISE CONSTITUCIONAL E LEGAL À LUZ DA HISTÓRIA.
}

\author{
THE THEORY OF THE CRIMINAL LAW OF THE ENEMY: A CONSTITUTIONAL AND \\ LEGAL ANALYSIS IN THE LIGHT OF HISTORY.
}

\author{
Fernando Tadeu Marques ${ }^{1}$
}

Hugo Leça Ribeiro²

\begin{abstract}
RESUMO
O presente estudo discorre sobre a teoria do direito penal do inimigo, que teve sua expansão e amadurecimento, pelo doutrinador alemão Günther Jakobs, no século passado que objetivou reduzir a criminalidade, por meio da instituição de penas rígidas, excluindo uma variedade de direitos daqueles considerados inimigos do Estado, retirando a personalidade destes, e não os considerando mais como pessoas. Este estudo teve como objetivo analisar além da teoria mencionada, averiguar para a possibilidade da instituição desta no ordenamento jurídico brasileiro. Ademais foram elencadas algumas legislações brasileiras com pequenas
\end{abstract}

\footnotetext{
${ }^{1}$ Professor, Advogado Criminalista. Doutorando em Direito e Mestre em Direito Penal pela Pontifícia Universidade Católica de São Paulo. Especialista pela Escola Paulista de Direito em Direito Público. Especialista pela Faculdade Anchieta em Docência no Ensino Superior. Bacharel em Direito pela Universidade Paulista. Exerce atividade docente como professor na graduação em Direito da Pontifícia Universidade Católica de Campinas (SP) e na pós-graduação de Direito Penal e Processo Penal da Pontifícia Universidade Católica de Poços de Caldas (MG); leciona na Escola Paulista de Direito (EPD) a disciplina Direito Penal Médico no Curso de pós-graduação de Direito Médico e Hospitalar; É Membro avaliador de artigos científicos na Universidade Central do Chile, na Universidade Federal de Santa Maria e no Instituto Brasileiro de Ciências Criminais. Integra como pesquisador na Universidade Federal de São Paulo (UNIFESP) o Grupo de Pesquisa Conflitos armados, massacres e genocídios na era contemporânea. É coordenador adjunto no IBCCRIM. E-mail: fernandotmarques@hotmail.com ${ }^{2}$ Bacharel em Direito pela Universidade Cruzeiro do Sul. Pós Graduando em Direito Civil e Processo Civil pela Universidade Cândido Mendes. Advogado inscrito na OAB. E-mail: hugolerib@gmail.com
} 
características do direito penal do inimigo. O trabalho se desenvolveu por meio do estudo da legislação e da doutrina, bem como dos aspectos históricos que nortearam para a criação do direito penal do inimigo. Desse modo, este estudo teve como resultado que se torna impossível a instituição deste sistema de direito no país, uma vez que a Constituição Federal veda a submissão de qualquer pessoa a tortura, tratamento desumano ou degradante, não fazendo distinção de ninguém, por mais perigoso que este venha a ser, estando todo o sistema punitivo estatal, delimitado a uma diversidade de princípios constitucionais, onde a dignidade da pessoa humana, se reflete por todo ordenamento jurídico.

PALAVRAS- CHAVES: direito penal do inimigo; teoria; penas.

\section{ABSTRACT}

The present study deals with the criminal law theory of the enemy, which had its expansion and maturation, by the German jurist Günther, in the last century that aimed to reduce crime by imposing rigid penalties, excluding a variety of rights of those considered enemies of the state, taking away the personality of these, and not considering them as people. This study aimed to analyze beyond the aforementioned theory, to investigate for the possibility of the institution of this in the Brazilian legal system. In addition some Brazilian legislations with little characteristics of the criminal law of the enemy were listed. The work developed through the study of legislation and doctrine, as well as the historical aspects that guided the creation of the criminal law of the enemy. As a result, it is impossible to institute this system of law in the country, since the Federal Constitution prohibits any person from being subjected to torture, inhuman or degrading treatment, making no distinction from anyone, however dangerous it may be. being, guiding, being all state action, delimited to a series of principles, having the dignity of the human person, as root, for all legal order.

KENYWORDS: criminal law of the enemy; theory; penalty.

\section{CONSIDERAÇÕES INICIAIS}

Ao se analisar a história da humanidade é possível presenciar diversas atitudes e pensamentos de delinquentes que fugiram do comum e do aceitável pela sociedade, fato que consequentemente ampliou o debate, acerca de quais medidas devem ser adotadas na atualidade, para reprimir o crescente aumento da criminalidade.

Com o aumento do acesso à informação na última década, a sociedade passou a conviver banhada de diversas informações, de cunho criminalista, presenciando 
cotidianamente os mais diversos crimes brutais e ocorrências de ações delitivas de grande perturbação. Consequentemente a sociedade ao se deparar com tais atitudes sanguinárias, reage pressionando o Estado, e conclamando para que se puna rigorosamente o delinquente, ansiando muitas vezes por punições expressamente vedadas pela Constituição Federal.

Desse modo surgem os questionamentos: realmente ações que prejudicam mais a sociedade, e por consequência são mais repudiadas devem ser reprimidas com medidas especiais? Seria correto diferenciar os tipos de criminosos de acordo com suas intenções, ações pretéritas e modalidade criminosa? Ademais, quais seriam as formas de punição destes?

A teoria do Direito Penal do Inimigo, enunciada pelo Professor e Doutor Günther Jakobs, surge justamente elencando soluções para a problemática do aumento da criminalidade, defendendo a possibilidade de divisão do direito penal em duas correntes: a dos cidadãos e a dos inimigos.

Narra a teoria, que para as pessoas de menor risco à sociedade, deve ser aplicado o Direito Penal do Cidadão (comum), sendo tais pessoas titulares de garantias e direitos que a legislação destina na atualidade a todos. Em contrapartida, os classificados como inimigos do Estado que oferecem alto risco à sociedade, não se reconhece as mesmas garantias de direitos, de modo a reprimir qualquer ação destes indivíduos a sociedade.

Acerca de tal aspecto Oliveira (2011) enfatiza que, se o indivíduo não oferece uma segurança cognitiva sobre sua conduta, é porque não reconhece o ordenamento jurídico, sua validade e imperatividade, devendo ser considerado como um inimigo e não apenas como um transgressor. $O$ autor expõe que um criminoso comum não nega a validade do ordenamento, apenas o infringe e acaba por sofrer uma pena que revalida contrafaticamente todo o sistema.

Silveira (2011) explana que o Direito Penal, se divide em dois seguimentos, um deles aplicável ao cidadão, de cunho simbólico, visando reprimir aquele que rejeita a 
norma, uma vez que, a infração praticada por este não resulta em ofensa grave a sociedade; e o outro destinado ao inimigo, caracterizado pelo aspecto físico da custódia de segurança, para evitar que o delinquente pratique futuros crimes, que atinjam a harmonia da sociedade.

Diante da breve explanação, tem se que a tese introduzida pelo professor Jakobs busca a aplicação da norma com maior intensidade para os delinquentes que não se intimidam com o ordenamento jurídico penal comum, a problemática é que na teoria tudo pode ser vislumbrando, entretanto ao caso concreto torna-se difícil a aplicação de tal teoria, visto os limites que a Constituição impõe para a aplicação das penas. É desse modo, que este trabalho, discorrerá de maneira detalhada sobre o Direito Penal do inimigo, enfatizando para o aumento das organizações criminosas, e a ineficácia do Estado no combate a estas.

\section{HISTÓRIA DO DIREITO PENAL DO INIMIGO.}

Não se tem precisão de quando e quem, surgiu e criou respectivamente, a teoria do Direito Penal do Inimigo, observa Lascano (2003) que desde o século XIX, já se utilizava da expressão Direito Penal do Inimigo, uma vez que com palavras semelhantes, em 1882, Von Liszt, em seu célebre programa de Marburgo, empregou a concepção ao se referir ao poder punitivo estatal como uma guerra para combater a criminalidade.

Não obstante, pode se afirmar que a teoria foi desenvolvida e amadurecida, pelo conceituado doutrinador Günther Jakobs, que explanou e divulgou a tese, da qual defendia a existência de um Direito Penal que combatesse de forma diferente os problemas sociais penais que o ordenamento jurídico comum não estava apto a sanar.

Moraes (2013) no que tange a parte histórica afirma que, em 1985 Jakobs apresentou o conceito de "Direito Penal do Inimigo" para a sociedade de Frankfurt, não recebendo a publicidade e a notoriedade que o tema necessitava. Somente em 1999 é 
que a teoria ora apresentada ganha força no setor jurídico, após a apresentação do tema perante o Congresso do Milênio. Em Berlim foram levantados diversos questionamentos acerca da teoria, que se repercutiram, nas regiões de língua portuguesa e espanhola.

O tema teve então um solavanco e ganhou notoriedade pública após os atentados terroristas que ocorreram em 11/09/2001 na cidade de Nova York. Isto porque, a ideia de Jakobs era a de separar o Direito Penal em duas grandes esferas, a primeira (chamada de Direito Penal do Cidadão) encarregada de lidar com as infrações cometidas pelos cidadãos, e a segunda (chamada de Direito Penal do Inimigo) que lidaria com os atos praticados pelos inimigos do Estado (nesta ocasião, terroristas). É desta forma que (JAKOBS, 2007, p. 21) inicia sua obra:

Quando no presente texto se faz referência ao Direito penal do cidadão e ao Direito penal do inimigo, isso no sentido de dois tipos ideais que dificilmente aparecerão transladados à realidade de modo puro: inclusive no processamento de um fato delitivo cotidiano que provoca um pouco mais que tédio - Direito penal do cidadão - se misturará ao menos uma leve defesa frente a riscos futuros - Direito penal do inimigo -, e inclusive o terrorista mais afastado da esfera cidadã é tratado, ao menos formalmente, como pessoa, ao the ser concedido no processo penal os direitos de um acusado cidadão. Por conseguinte, não se trata de contrapor duas esferas isoladas do Direito penal, mas de descrever dois polos de um só mundo ou de mostrar duas tendências opostas em um só contexto jurídico-penal. Tal descrição revela que é perfeitamente possível que estas tendências se sobreponham, isto é, que se ocultem aquelas que tratam o autor como pessoa e aquelas outras que tratam como fonte de perigo ou como meio para intimidar aos demais.

Após os ataques terroristas citados, o mundo entrou em estado de alerta para possíveis investidas do mesmo escalão. Assim, os países passaram a discutir atitudes, tomando posicionamentos a fim de criar obstáculos perante tais investidas criminosas.

Por muitas vezes tais obstáculos infringiram tratados de Direito Humanos e garantias fundamentais previstas no ordenamento interno de cada Estado, todavia os líderes estatais viam-se obrigados a não seguirem a risca o ordenamento jurídico 
adequado, pois só assim combateriam de forma severa e na mesma proporcionalidade as atitudes brutais dos terroristas e afins.

\subsection{O Direito Penal do Inimigo e a Alemanha Nazista}

O projeto nacional-socialista foi apresentado à humanidade em 1944, entretanto suas ideias vieram a tona, recentemente, por Edmund Mezger, com a obra o Direito Penal de Seu Tempo.

Greco (2011) explana acerca do projeto do partido nacional socialista, considerando que tal foi um dos mais terríveis da história do Direito Penal, que propôs, dentre muitas outras brutalidades: a castração dos homossexuais; a prisão por tempo indeterminado dos considerados antissociais; e a esterilização com o intuito de evitar a propagação, daqueles considerados associas e inúteis.

Na mesma panorâmica Prado (2009) disserta que, embora a construção teórica do Direito Penal do Inimigo não tenha sido desenvolvida na época de propagação do pensamento nazista, não se tem dúvida de que a teoria possui traços típicos das leis penais e processuais aplicadas na Alemanha nazista, visto que, ambos pensamentos, cultuam a segregação e o autoritarismo.

\section{CONCEITO E CARACTERIZAÇÃO DO DIREITO PENAL DO INIMIGO}

O Direito Penal do Inimigo trata-se de uma teoria utilizada para prover um tratamento jurídico penal distinto aos indivíduos que por conta de cometer ou planejarem cometer atos extremamente lesivos ao Estado, passam a não mais merecer ser tratados como cidadãos, sendo considerados como inimigos do Estado.

Para o Direito Penal do Inimigo, impera o tratamento penal máximo no combate as atitudes que colocariam em cheque toda uma sociedade, desafiando o governo e Estado desta. 
O Direito Penal seria dividido então em duas esferas: a primeira seria o Direito Penal do Cidadão (ordem jurídica que respeitaria as garantias adquiridas pelos cidadãos de um Estado, no que tange a aplicação das penas); e a segunda seria o Direito Penal do Inimigo, instrumento disciplinado para agir com extrema urgência frente aos inimigos do Estado.

$\mathrm{Na}$ teoria o primeiro Direito é aplicado aos cidadãos que praticam esporadicamente delitos, não fazendo do crime um objetivo de vida, ou uma forma de viver. Já o segundo Direito é utilizado para combater os indivíduos que se dedicam vigorosamente à vida criminosa, estando estes, constantemente oferecendo riscos à sociedade e ao Estado. Este inimigo do Estado fica suscetível a uma coerção severa, perdendo o direito de diversas garantias e direitos protegidos.

Aller(2011, p. 68) sobre a caracterização da figura do inimigo e sobre as bases teóricas para entender quem é essa figura, esclarece que:

El derecho penal del enemigo está planteado en términos de que hay individuos que atacan consistentemente a un sistema social regido por el Derecho. Para la base de su elaboracíon recurre a la mencionada Teoría de los Sistemas de Luhmann. Em opinión de Jakobs, quien agrede constantemente al sistema es um enemigo: y éste pierde el rol de persona, porque incumple el deber del ciudadano concerniente al contrato social.

Com enorme brilhantismo Prado( 2009) conceitua Direito Penal do Inimigo:

O Direito Penal do Inimigo é um Direito Penal de exceção, feito regra. Trata-se de uma construção teórica fundamentada essencialmente na distinção entre cidadãos e não-cidadãos (ou inimigos) que, no âmbito dogmático, consiste na própria separação entre pessoas e não-pessoas, conduzindo à distinção entre dois polos de regulação normativa penal, coexistentes no ordenamento jurídico: um dirigido ao cidadão e outro ao inimigo. Desse modo, de um lado, o Direito penal do cidadão define e sanciona delitos cometidos por pessoas de forma incidental, ou seja, delitos que representam um abuso nas relações sociais de que participam. Assim, o cidadão oferece a chamada "segurança cognitiva mínima", ou seja, a garantia de que submetem ao preceito normativo e, por isso, são chamados a restaurar a sua vigência por meio da 
imposição sancionatória. Por essa razão, esses indivíduos continuam a ser considerados pessoas e, portanto, cidadãos aptos a fruir de direitos e garantias assegurados a todos que partilhem desse status.

No que tange as características do Direito Penal do Inimigo, tem se que este apresenta características próprias, Prado (2009) explana que pode ser mencionado como traços marcantes desta teoria, a antecipação da punibilidade, buscando atingir momentos anteriores à realização do fato delituoso, punindo dessa maneira os atos preparatórios do crime.

Podem ser elencadas quatro características marcantes, no que tange ao Direito Penal do Inimigo, sendo elas: penas mais rígidas; a flexibilização ou não aplicação das garantias fundamentais; a possibilidade de penas desproporcionais aos fatos praticados, tendo como efeito exemplar; e a antecipação da punibilidade, ou seja, a punição dos atos preparatórios, algo que, em regra, é inaceitável em nosso ordenamento jurídico.

Gomes (Direito Penal do Inimigo) vai mais além e nos apresenta dez características do Direito Penal do Inimigo:

a) o inimigo não pode ser punido com pena, sim, com medida de segurança; b) não deve ser punido de acordo com sua culpabilidade, senão consoante sua periculosidade; $c$ ) as medidas contra o inimigo não olham prioritariamente o passado (o que ele fez), sim, o futuro (o que ele representa de perigo futuro); d) não é um Direito retrospectivo, sim, prospectivo; e) o inimigo não é um sujeito de direito, sim, objeto de coação; f) o cidadão, mesmo depois de delinquir, continua com o status de pessoa; já o inimigo perde esse status (importante só sua periculosidade); g) o Direito penal do cidadão mantém a vigência da norma; o Direito penal do inimigo combate preponderantemente perigos; h) o Direito penal do inimigo deve adiantar o âmbito de proteção da norma (antecipação da tutela penal), para alcançar os atos preparatórios; i) mesmo que a pena seja intensa (e desproporcional), ainda assim, justifica-se a antecipação da proteção penal; j) quanto ao cidadão (autor de um homicídio ocasional), espera-se que ele exteriorize um fato para que incida a reação (que vem confirmar a vigência da norma); em relação ao inimigo (terrorista, por exemplo), deve ser 
interceptado prontamente, no estágio prévio, em razão de sua periculosidade.

Enquanto no Direito penal comum o cidadão delinquente jamais perde sua qualidade de pessoa, no Direito penal do inimigo tal perda é uma das características basilares de sua aplicação.

Assim, é possível imaginar que facilmente poderiam ser aplicadas as penas de tortura, pena de morte, de exílio, e dentre outras, proibidas expressamente pela Constituição Federal, e pelos tratados de direitos humanos, dos quais o Brasil é signatário.

Há interessante passagem no livro de Hobbes (1999, p. 237) em que o filósofo descreve que a punição do inimigo é cabível de qualquer medida, visto que os danos infligidos a quem é um inimigo declarado não podem ser classificados como penas, dado que esse inimigo nunca esteve sujeito à lei e portanto não pode transgredi-la.

\section{QUEM É O INIMIGO?}

Esta questão é sem dúvida uma das mais intrigantes a se fazer acerca da teoria do Direito Penal do Inimigo. Afinal de contas, quem seriam estes indivíduos denominados inimigos do Estado. Para que se tenha proximidade da resposta se faz necessário uma análise da parte filosófica que ronda a tese do Direito Penal do Inimigo, para posteriormente tentar inserir a ideia de 'inimigo' na sociedade.

Para Rousseau (2001) inimigo é aquele indivíduo que rompe com o Contrato Social, é o malfeitor sendo aquele que ameaça a sociedade e o direito social, deixando de ser um membro do Estado e passando a ser visualizado como inimigo público.

Hobbes (1999) considera como inimigo o sujeito que comete alta traição contra o Estado, que deve puni-lo não mais como seu súdito (membro), mas sim como inimigo. Hobbes afirma que quando o indivíduo trai o Estado ele regressa ao estado natural do homem. 
Kant apud Jakobs (2007, p. 26 ss), descreve que inimigo é aquele indivíduo que lesiona a todo momento quem está ao seu lado, que ameaça constantemente os cidadãos de um determinado Estado. Assim, este sujeito não mais participa das relações de um Estado, devendo portanto ser excluído deste mesmo, não podendo mais ser tratado como pessoa, e sim como um inimigo.

Zaffaroni (2015, p. 21) colabora para a discussão sobre a caracterização do conceito ou ideia de quem é o inimigo, destacando a sua origem:

A negação jurídica da condição de pessoa ao inimigo é uma característica do tratamento penal diferenciado que lhe é dado, porém não é a sua essência, ou seja, é uma consequência da individualização de um ser humano como inimigo, mas nada nos diz a respeito da individualização em si mesma. Quando se pergunta a respeito desta essência, fica inegável que, conforme à doutrina que mais se aprofundou no tema e que a tratou de forma mais desabrida - ou seja, sem dissimular a questão nem fugir do problema -, o conceito tem origem no direito romano e o autor que trabalhou o tema com maior coerência na teoria política foi Carl Schmitt, que, por sua vez, não fez mais do que resgatar e precisar o conceito tradicional proveniente do direito romano.

Jakobs (2007, p. 35) afirma que inimigos são indivíduos destinados a viverem afastados de maneira duradoura do direito positivado pelo Estado. $\mathrm{O}$ autor aponta para algumas espécies de crimes e criminosos que poderiam ser considerados como inimigos do Estado, quais sejam: crimes contra a liberdade sexual, crimes de caráter econômico, membros de organização criminosa, terroristas, e todos aqueles que pratiquem e se dediquem às atividades criminosas graves, colocando a sociedade em risco.

Assim, a intenção do Direito penal do inimigo é classificar como adversário do Estado o indivíduo que pratica crimes graves e perigosos e assim o faz de maneira contínua e dolosamente.

Prado (2009) mais uma vez demonstra de maneira concisa e pontual o que se define por inimigo: 
O "inimigo" é considerado o "irreconciliavelmente oposto", isto é, aquele que apresenta um distanciamento duradouro e não incidental das regras de Direito, verificado pelo seu comportamento pessoal, profissão, vida econômica, etc. As relações sociais desses indivíduos desenvolvem-se à margem do Direito e, por isso, não oferecem a segurança cognitiva mínima necessária para que sejam considerados como pessoas. Essa condição de inimigo radica, sobretudo, em sua desconsideração enquanto pessoa, conceito que, segundo essa teoria, tem um viés normativo. Assim, pessoa não é um dado natural, inerente a todo e qualquer indivíduo, mas está relacionado ao destino das expectativas normativas. É dizer: a atribuição dessa condição social - pessoa - a um indivíduo depende do grau de satisfação das expectativas normativas que ele é capaz de prestar. O inimigo, portanto, seria incapaz de atender o mínimo de expectativas normativas, pois, em realidade, ele não só refuta a legitimidade do ordenamento jurídico, como busca a sua destruição.

Diante do exposto neste capítulo entende-se que, a classificação do indivíduo como inimigo do Estado está entre umas das mais severas e extremas tarefas, ao passo que o Estado teria que avaliar com grande cautela e perspicácia a situação fática e o perigo que o delinquente ofereça à sociedade, para que desse modo um cidadão comum não sofra as sanções destinadas aos indivíduos considerados como inimigos.

\section{A APLICABILIDADE DO DIREITO PENAL DO INIMIGO NO BRASIL}

Torna-se quase que impossível pensar na aplicação do direito penal do inimigo em solo brasileiro uma vez que a Constituição Federal, veda expressamente alguns tipos de penas.

A Carta Magna elenca no art. 5, XLVII, que não haverá penas: de morte, salvo em casos de guerra declarada; de trabalhos forçados; de banimento; e cruéis. Há de se enfatizar ainda que ninguém no país pode ser privado de seus bens ou de sua liberdade sem o devido processo legal (art 5, LIV), fato que contraria a teoria ora aqui estuda, uma vez que, esta além de permitir a punibilidade antecipatória, excluí a possibilidade da aplicação de direitos e garantias fundamentais. 


\section{Vertentes do IDireito}

ISSN n' 2359-0106

Vol. 5, n. 1, 2018.

O próprio caput do art. 5o Constituição Federal prevê que todos são iguais perante a lei, sem distinção de qualquer natureza, garantindo aos brasileiros e até mesmo os estrangeiros aqui residentes, a inviolabilidade do direito à vida, à liberdade, à igualdade, à segurança e à propriedade. Ademais, o inciso III, do mesmo artigo, positiva que ninguém será submetido à tortura nem a tratamento desumano ou degradante.

Há de se verificar ainda que o Brasil é signatário da Convenção Americana sobre Direitos Humanos, conhecida como (Pacto San Jose da Costa Rica), assinada em 1969, que adentrou o ordenamento jurídico brasileiro com força vinculante por meio do Decreto N. 678, de 6 de novembro de 1992. A Convenção expõe que, ninguém deve ser submetido a torturas, nem a penas ou tratamentos cruéis, desumanos ou degradantes. Toda pessoa privada da liberdade deve ser tratada com o devido respeito a dignidade da pessoa humana, inerente ao ser humano.

Ademais, constitui cláusula pétrea da Constituição Federal, não podendo, pois, ser objeto de deliberação a proposta que tende a abolir, os direitos e garantias individuais. (art. 60, $\S 4^{\circ}$ ). Ou seja vislumbra-se que caso alguma legislação tente positivar de modo legal o Direito Penal do Inimigo no ordenamento jurídico, esta poderá será inconstitucional.

No próximo capítulo, este trabalho apresentará algumas legislações que podem em tese conter alguns traços do direito penal do inimigo, entretanto não condiz com o pensamento dos pesquisadores deste trabalho.

\subsection{Lei do Abate}

No ano de 1986 surgiu no ordenamento jurídico brasileiro a lei n. $7.565 / 86$, que dentre outras disposições regulava o tratamento dado as aeronaves hostis e suspeitas de transportarem drogas ilícitas. Inicialmente o tratamento dado era 0 de deter a 
aeronave para averiguação, e outras medidas penais cabíveis, conforme o artigo citado abaixo:

Art. 303. A aeronave poderá ser detida por autoridades aeronáuticas, fazendárias ou da Polícia Federal, nos seguintes casos:

I - se voar no espaço aéreo brasileiro com infração das convenções ou atos internacionais, ou das autorizações para tal fim;

II - se, entrando no espaço aéreo brasileiro, desrespeitar a obrigatoriedade de pouso em aeroporto internacional;

III - para exame dos certificados e outros documentos indispensáveis;

V - para verificação de sua carga no caso de restrição legal (artigo 21) ou de porte proibido de equipamento (parágrafo único do artigo 21); $\mathrm{V}$ - para averiguação de ilícito.

Já no ano de 1998, a Lei n. 9.614 inseriu a medida de destruição de aeronaves caso se vislumbrasse que estas sobrevoassem o país de forma hostil ou, que recaísse sobre estas, suspeitas de que transportassem produtos entorpecentes, ilícitos.

No ano de 2004 foi editado o Decreto 5.144, do qual inseriu na Lei ora estudada os métodos para se efetuar o abate de aeronaves hostis.

Vale chamarmos atenção ao artigo 5ํำ do referido decreto:

Art. 5 A medida de destruição consiste no disparo de tiros, feitos pela aeronave de interceptação, com a finalidade de provocar danos e impedir o prosseguimento do vôo da aeronave hostil e somente poderá ser utilizada como último recurso e após o cumprimento de todos os procedimentos que previnam a perda de vidas inocentes, no ar ou em terra.

O Estado ao permitir esta abertura de fogo permite uma exceção à vedação da pena de morte, e aos princípios da presunção de inocência, da ampla defesa e do contraditório, sem falar na ofensa à garantia fundamental do direito à vida.

Entretanto tais exceções são constitucionais, pois previnem um mal maior que poderia ser causado ao Estado. O bem da coletividade, se sobrepõe ao direito à vida. 


\subsection{A Lei de Drogas}

Tal legislação está prevista na Lei n. 11.343 de 2006, onde estão contidas, as tipificações penais para os atos que envolvam desde a preparação até a traficância de substâncias tidas como drogas (fixada mediante portaria da Anvisa).

Há pelo menos dois artigos importantes a ser citados: o primeiro trata-se do artigo 28, que dispõe sobre o porte de drogas para uso pessoal; e o segundo artigo 44 que veda diversos direitos aos que se enquadrarem nos artigos 33 , $\S 1^{\circ}$, 34 e 37.

Acerca do artigo 28 da referida lei, é forte e crescente o entendimento pela sua inconstitucionalidade tendo em vista que pune o usuário de drogas por portar tais substâncias.

Embora o legislador e alguns doutrinadores defendam que o bem jurídico tutelado pelo referido artigo é a saúde pública, quem ataca pela inconstitucionalidade da norma defende que é incabível que um usuário não possa portar drogas na justificativa de expor em risco a saúde pública.

Vale lembrar que o direito penal brasileiro não pune a autolesão, o que ocorre ao sujeito que faz uso de substâncias entorpecentes. Desta maneira, o Estado ao punir criminalmente um usuário de drogas que está portando substância para seu uso pessoal aparentemente parece ser severo demais, chegando até mesmo a ignorar a vedação de punição à autolesão.

Apenas para finalizar a questão acerca do artigo 28 da referida lei, nota-se na prática que por muitas vezes usuários de entorpecentes que traziam consigo quantidade de droga para uso próprio acabaram sendo enquadrados como praticantes do tipo penal previsto no artigo 33 da mesma lei, ou seja, passaram a responder a um processo criminal como traficantes e não como usuários.

Assim, o que ocorre na prática é a imposição de uma figura criminal na qual recai uma pena mais severa e maior a um usuário de drogas comum. Nesse diapasão podemos ver a mão de ferro do Estado ao querer combater de qualquer forma os 
usuários de drogas, não importando se apenas estão se auto lesionando, ou que de outra forma faz com que respondam como se traficantes fossem.

Em relação ao artigo 44 mencionado anteriormente, colacionamos abaixo seu texto literal para analisarmos as vedações e rigorosidades previstas:

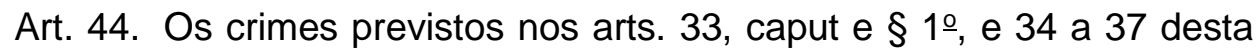
Lei são inafiançáveis e insuscetíveis de sursis, graça, indulto, anistia e liberdade provisória, vedada a conversão de suas penas em restritivas de direitos.

Parágrafo único. Nos crimes previstos no caput deste artigo, dar-se-á o livramento condicional após o cumprimento de dois terços da pena, vedada sua concessão ao reincidente específico.

Nota-se ao tratamento mais rigoroso dado pelo legislador aos traficantes de drogas e a quem pertença a um grupo destinado à prática dos delitos de traficância de entorpecentes.

As vedações quanto a fiança, anistia, graça e indulto para os crimes previstos nos artigos 33, caput, §1 e 34, não insurgem novidade para o ordenamento jurídico, pois já haviam tais vedações conforme a Lei dos crimes hediondos, lei 8.072/90.

Quanto às vedações a quem incorre nos artigos 35 e 37, estas parecem violar o princípio da proporcionalidade e da individualização da pena, pois tais artigos não estão previstos no rol de delitos hediondos e mesmo assim recebem igual tratamento, como se estivessem.

Acerca das vedações da conversão das penas privativas de liberdade em restritivas de direito e a vedação da liberdade provisória nossa Corte Suprema já se manifestou pela inconstitucionalidade das mesmas (HC 97256 e HC 104339, respectivamente).

Mesmo após tais julgados no Supremo Tribunal Federal é nítida a vontade do legislador em dar um tratamento penal mais severo a quem pratica os delitos ora analisados. 


\subsection{Lei das Organizações Criminosas}

A Lei que dispôs acerca das organizações criminosas até agosto de 2013 foi a de n. 9.034 de 1995. Nela se pode observar algumas características que regiam um tratamento severo para os membros de organizações criminosas: o acesso a dados bancários dos membros, interceptações telefônicas, a vedação à liberdade provisória (com ou sem fiança), regime inicial fechado para cumprimento de pena e por fim a vedação à apelação em liberdade.

Portanto, pode se notar algumas características do chamado Direito Penal do Inimigo, utilizado pelo legislador, provendo um tratamento diferenciado e severo aqueles que pertenciam as organizações criminosas.

Tal lei foi recentemente revogada pela lei n. 12.850, de 02 de agosto de 2013. $\mathrm{Na}$ nova legislação não há mais a presença de tantas vedações que ocorriam na legislação anterior.

Contudo, a nova legislação ainda prevê a quebra de sigilos bancários e a interceptação telefônica, ademais, deu-se nova redação ao crime de quadrilha (artigo 288, do Código Penal), agora denominado de "associação criminosa", que pune associações de três ou mais pessoas para o fim específico de cometer crimes.

\subsection{Regime Disciplinar Diferenciado (RDD)}

A lei de n. 10.792, que passou a vigorar em $1^{\text {o }}$ de dezembro de 2003, oportunidade na qual alterou alguns artigos dispostos na Lei de Execuções Penais (LEP), lei n. 7.210, de 1984. Tal alteração acabou por introduzir o chamado Regime Disciplinar Diferenciado (RDD), tratando-se então de uma punição penal máxima em termos de encarceramento, ou seja, a ultima ratio do Direito Penal brasileiro em termos de execução penal. 
Seria decretado tal regime diferenciado aos presos mais perigosos, oportunidade na qual seriam estes deslocados a verdadeiras fortalezas carcerárias, onde imperaria o mínimo de contato possível com o mundo exterior (através de poucas visitas familiares, biblioteca e 02 horas de banho de sol) e visaria o máximo possível de isolamento do preso.

Uma característica deste sistema prisional diferenciado é que conforme previsão legal (artigo 52, $\S^{\circ}$ e $\S^{2}{ }^{\circ}$ da referida lei) é possível impor este tratamento a um detento apenas baseando-se em sua estimada periculosidade.

A doutrina majoritária brasileira entende que o RDD deveria ser extinto de nosso ordenamento, pois configura extremo abuso aos direitos e garantias fundamentais que todos os seres humanos deveriam se valer.

Com muito afinco a Defensora Pública Marta Xavier de Lima Gouvêa (2011) se mostra totalmente contra o RDD:

Ao analisar o RDD, é possível tecer um comentário a respeito do princípio da humanidade das penas, que prega que o condenado ou o provisoriamente preso como violador da ordem jurídica deve ter direitos restringidos, mas não deixa de carregar consigo sua ínsita dignidade humana, devendo-se evitar um sofrimento desnecessário ao preso. A inconstitucionalidade do RDD é gritante, de um barulho ensurdecedor, já que é de conhecimento geral que o aprisionamento e a exclusão social não são soluções para a violência ou criminalidade.

Ainda, continua a mesma Defensora Pública, traçando paralelo entre o RDD e o Direito penal do inimigo:

Diante da análise dos temas objeto de estudo, tornou possível traçar um paralelo entre o Direito Penal do Inimigo e o Regime Disciplinar Diferenciado, ambos são de ensurdecedora inconstitucionalidade, de negação do Direito constituído, das garantias adquiridas a custa de muita luta e de muito sangue derramado, um verdadeiro retrocesso na Ciência do Direito que se permite ser manipulada de acordo com situações insurgentes no território nacional e que nos transforma em bobos da corte. É inadmissível que o Poder Legislativo alheio ao clamor 
da comunidade jurídica promulgue leis em função do clamor social, transparecendo a sua incompetência e opta por um Direito Penal Simbólico que acalma os ânimos dos desavisados que não percebem que leis promulgadas em função de clamor social se transformam em letra morta para os verdadeiros delinquentes, pois vivemos o Direito Penal da seletividade, onde os eleitos para abarrotar os cárceres são os menos favorecidos e nós operadores do direito muitas vezes quedamos inerte diante da injustiça que mata as esperanças, que exclui e cria regimes de desesperança como o aclamado pelo povo e conhecido pela alcunha de RDD.

\section{Crítica ao Direito Penal do Inimigo}

No universo da não tão recente assim tese do Direito Penal do Inimigo é possível de observar a mesma ocorrência de divisões favoráveis e contrárias à sua aplicação e fundamentos. Contudo, enormes são as críticas que giram em torno de tal teoria.

Inicialmente, cita-se a crítica de Meliá apud Jakobs (2007, p. 81), visto que esta possa ter sido a primeira oposição aos pensamentos de Jakobs (embora ambos evitem usar a palavra oposição, percebe-se que há um conflito entre seus pensamentos), assim, segue abaixo trecho que demonstra a insatisfação de Meliá perante a ideia de se punir os atos de cogitação e de preparação num Estado Democrático de Direito:

(...) fica claro que numa sociedade moderna, com boas razões funcionais, a esfera de intimidade atribuída ao cidadão não pode ficar limitada aos impulsos dos neurônios - algo mais que a liberdade de pensamento -. Isto cristaliza na necessidade estrutural de um fato como conteúdo central do tipo (Direito penal do fato em lugar de Direito penal do autor).

Esta crítica de Meliá é nítida no sentido de não ser possível a adoção de um direito penal do autor, ou além, transmutar este autor em inimigo estatal.

Prosseguindo, outra crítica acerca da teoria, gira em torno do desrespeito às garantias fundamentais adquiridos com tanto esforço ao longo dos anos. 
Realizar então uma regressão a um estágio jurídico a quo, onde eram permitidas diversas penais cruéis, em que o devido processo legal não era respeitado ou sequer existia, está totalmente fora de questão e é inadmissível, independente do motivo.

Polaino Orts (2014, p. 188) colabora com uma reflexão necessária sobre a conceituação do inimigo e a ótica funcionalista, onde destaca:

Para o funcionalismo o conceito de inimigo e, em geral, a instituição do Direito penal do inimigo unicamente em sentido normativo e social na medida em que cumprem uma função de estabilização normativa, isto é: na medida em que são funcionais. Esta funcionalidade do verdadeiro conceito de Direito penal do inimigo é frontalmente oposta ao populismo punitivo e ao Direito penal simbólico. O populismo punitivo propugna, em definitivo, um Direito penal simbólico, não real e sim fictício, fundado na ideia superficial de uma "hipocrisia punitiva" que pode dar a aparência de um Direito penal melhor, mas que afinal, é devastador para as garantias jurídicas do Estado de Direito.

Outro ponto muito criticado é acerca da intitulação de 'inimigo', ou seja, ao dar tamanho poder a um Estado para que este determine quem é inimigo e quem não é, pode abrir enorme lacuna de risco social, existindo então a possibilidade de fixar-se cidadãos de hoje em inimigos de amanhã, isto traria enorme insegurança jurídica e social.

Deste modo se posiciona Greco (2005), argumentando que não se pode afastar todas as conquistas que foram dadas em doses homeopáticas ao longo dos anos, sob o falso argumento do cidadão versus inimigo, não sendo possível reconhecer o dia de amanhã, podendo chegar um louco ao poder e dizer que é inimigo também, quem seja contrário a teoria.

Outra questão polêmica é sobre retirar o caráter de pessoa e dar-Ihe o de inimigo, assim, em tese este inimigo seria incorrigível. Para quem critica com afinco o Direito penal do inimigo defende que jamais pode-se afirmar que alguém é incorrigível e o Estado deverá buscar meios para tentar ressocializar este indivíduo. 
Greco (2005) se manifesta exercendo mais uma crítica, argumentando que não se pode desistir do homem, sobre o falso argumento de este ser incorrigível, de possuir um defeito de caráter que o impede de agir conforme os demais cidadãos.

Sánchez (2011, p. 219) põe em destaque tanto uma objetiva expansão como uma exasperada antecipação da intervenção do Direito Penal, e diz:

Enfim, o Direito Penal dos direito humanos está contribuindo lamentavelmente à ruptura das garantias clássicas do Direito Penal: se eliminam as garantias de lei escrita e taxatividade, de coisa julgada e de irretroatividade, se está construindo um Direito Penal distinto ou, melhor, algo distinto do Direito Penal sobre cuja virtualidade contaminante do conjunto do ordenamento não cabe dúvida alguma.

Prado (2009), defende que não há nenhum ponto positivo em adotar a teoria do Direito Penal do Inimigo:

O Direito Penal compatível com um Estado Democrático de Direito deve ser liberal, democrático e garantista. Logo, uma teoria que se fundamente na separação entre pessoas e não-pessoas, a partir de um conceito meramente normativo, descartando flagrantemente o aspecto ontológico da condição de ser responsável e capaz de se portar conforme ou contra o preceito normativo inerente a todo ser humano, criando, dessa forma, uma "pessoa normativizada", não possui qualquer reflexo positivo. De outro lado, essa discussão não teria relevância em um Estado totalitário, em que o Direito Penal como um todo é voltado para o combato aos "inimigos" do Estado. Todavia, não se pode afirmar que todas as formas de delinquência devam ser tratadas da mesma forma. O Estado pode utilizar os próprios mecanismos para possibilitar persecução e punição mais eficazes a determinadas formas de criminalidade, sem rechaçar os preceitos Ihe fundamentam, por meio do fortalecimento de medidas de prevenção, aparelhamento e modernização de instituições já existentes, dificultar a concessão de certos benefícios processuais e de execução penal com base em requisitos objetivos, sem que isso implique a supressão de tais benefícios, etc.

São vastos os entendimentos de doutrinadores brasileiros que afastam com todas as suas forças a mínima possibilidade de ser aplicado o Direito penal do inimigo em qualquer caso dentro do ordenamento jurídico brasileiro. 


\section{CONSIDERAÇÕES FINAIS:}

Mediante a tudo que foi exposto e as diversidades de tipos penais existentes para a coibição da criminalidade, há de se reconhecer que o país, sem sombra de dúvida anseia para a redução da criminalidade, e que este tem se esforçado, basta verificar os mecanismos legais: de combate às organizações criminosas (Lei 12.850/13); de coibição da participação de presos, na criminalidade, instituindo um regime diferenciado a estes (Lei 10.792/03); o combate ao tráfico de drogas (11.343/06); bem como a proteção da soberania do território brasileiro (Lei 9.614/88)

A problemática é que a criminalidade não tem diminuído no país, fato que consequentemente faz com que a sociedade vislumbre apenas na instituição de modelos punitivos tormentosos, investidos de penas rígidas como fator para a diminuição dos atos criminosos.

Uma vez instalado o direito penal do inimigo no Brasil, além de se ter graves violações de diretos e garantias fundamentais inerentes ao ser humano, por sua personalidade, se instalará ainda no país, um grande abalo constitucional, remetendo a Carta Magna aos tempos passados, onde tal tinha apenas um caráter político e não vinculante.

A própria história é capaz de confirmar a capacidade destruidora, de governos autoritários, basta analisar em plano mundial as consequências do grande holocausto instalado pelo autoritarismo e segregacionismo de Hitler, onde os judeus na época foram considerados inimigos do Estado, pelo simples motivo de pertencerem a uma etnia.

Ademais a teoria aqui estuda é repleta de subjetivismo uma vez que não é capaz de descrever quem seriam os inimigos de cada Estado.

Desse modo conclui-se que o aumento da criminalidade está atrelado a vários fatores, a própria corrupção estatal pode ser elencada como catalizador para o aumento das empreitadas criminosas. De imediato se faz necessário desmistificar do imaginário 
da população que as penas de morte, de tortura, dentre outras dotadas de rigidez e crueldade, são capazes de resolver um problema que ultrapassa os limites legais. Embora seja um argumento considerado clichê, o investimento em educação, a redução das desigualdades sociais, continuam sendo o melhor mecanismo para a redução da criminalidade. Um país que não investe em educação, consequentemente precisa investir no sistema penitenciário, profético ou não, Darcy Ribeiro, no século passado, atentou para tal hipótese, que vem sendo confirmada diariamente.

\section{REFERÊNCIAS}

ALLER, Gérman. Coloquios Penales: Cuestiones dogmáticas, político-criminales y criminológicas. Montevideo: Calos Alvares Editor, 2011.

D'URSO, Luiz Flávio Borges. Crise na Segurança Pública de São Paulo. Revista Jurídica Consulex, Ano XVI - número 381, 1ํ de dezembro de 2012.

CUNHA, Rogério de Vidal. Doutrina: O Regime Disciplinar Diferenciado, 0 Simbolismo Penal e o Princípio da Humanidade das Penas.. Disponível em: <http://www.uj.com.br/Publicacoes/Doutrinas/default.asp?action=doutrina\&coddou=244 7> Acesso em 01 de set. de 2017.

GOMES, Luiz Flávio. Tendências político-criminais quanto à criminalidade de bagatela. São Paulo: RBCCRIM, 1992.

GOUVÊA, Marta Xavier de Lima. Direito Penal do Inimigo e Regime Disciplinar Diferenciado. Texto enviado ao Jurisway em 25/01/2011. Disponível em <http://www.jurisway.org.br/v2/dhall.asp?id_dh=5355>. Acesso em: 13 de jul. de 2017.

GRECO, Luís. Sobre o chamado Direito Penal do Inimigo. Revista da Faculdade de Direito de Campos, Ano VI, № 7 - Dezembro de 2005. Disponível em <http://fdc.br/Arquivos/Mestrado/Revistas/Revista07/Docente/07.pdf.> Acesso em: 20 de set. 2017. GRECO, Rogério. Direito Penal do Inimigo. Artigo disponibilizado no website <http://www.rogeriogreco.com.br/?p=1029>. Acesso em: 28 de ago. de 2017. 
HOBBES, Thomas. Leviatã ou Matéria, Forma e Poder de um Estado Eclesiástico e Civil. Trad. João Paulo Monteiro e Maria Beatriz Nizza da Silva. São Paulo, Nova Cultural Ltda, 1999.

LASCANO, Carlos Julio. La Cruzada de Ricardo Nuñez contra el Derecho Penal Autoritário. Disponível em <www.carlosparma.com.ar>. Acesso em: 03 de set. de 2017.

NORONHA, E. Magalhães. Direito penal. São Paulo: Saraiva. 2001.

OLIVEIRA, Rodrigo Szuecs de. Da sociedade de risco ao direito penal do inimigo: tendências de política criminal. Instituto Brasileiro de Ciências Criminais (IBCCRIM), 2011.

POLAINO ORTS, Miguel. Lições de direito penal do inimigo. São Paulo: LiberArs, 2014.

PRADO, Luiz Regis. Direito penal do Inimigo. Entrevista concedida à Carta Forense em 03 de março de 2009. Disponível em:

<http://www.cartaforense.com.br/conteudo/entrevistas/direito-penal-do-inimigo/3624> Acesso em: 04 set. de 2017.

SÁNCHEZ, Jesús María Silva. Expansão do Direito Penal: aspectos da política criminal nas sociedades pós-industriais. Trad. Luiz Otavio de Oliveira Rocha. 2. ed. São Paulo: Revista dos Tribunais. 2011.

WACQUANT, Loic. As prisões da miséria. Rio de Janeiro: Jorge Zahar, 2001, pág. 26. Apud GRECO, Rogério. Direito Penal do Inimigo. Disponível em <http://www.rogeriogreco.com.br/?p=1029 >. Acesso em: 28 de ago. de 2017.

ZAFFARONI, Eugênio Raúl. O inimigo no direito penal. Trad. Sérgio Lamarão. Rio de Janeiro. Revan. 2015. 